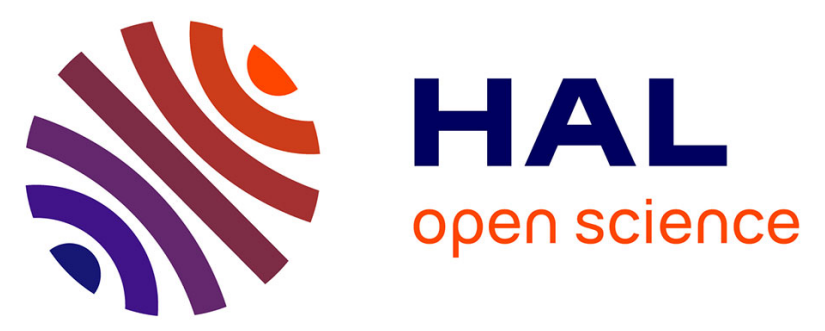

\title{
Half-Sandwich Nickel(II) NHC-Picolyl Complexes as Catalysts for the Hydrosilylation of Carbonyl Compounds: Evidence for NHC-Nickel Nanoparticles under Harsh Reaction Conditions
}

Franck Ulm, Saurabh Shahane, Lai Truong-Phuoc, Thierry Romero, Vasiliki Papaefthimiou, Matthieu Chessé, Michael J Chetcuti, Cuong Pham-huu, Christophe Michon, Vincent Ritleng

\section{- To cite this version:}

Franck Ulm, Saurabh Shahane, Lai Truong-Phuoc, Thierry Romero, Vasiliki Papaefthimiou, et al.. Half-Sandwich Nickel(II) NHC-Picolyl Complexes as Catalysts for the Hydrosilylation of Carbonyl Compounds: Evidence for NHC-Nickel Nanoparticles under Harsh Reaction Conditions. European Journal of Inorganic Chemistry, In press, 2021 (30), pp.3074-3082. 10.1002/ejic.202100371 . hal03308504

\author{
HAL Id: hal-03308504 \\ https://hal.science/hal-03308504
}

Submitted on 29 Jul 2021

HAL is a multi-disciplinary open access archive for the deposit and dissemination of scientific research documents, whether they are published or not. The documents may come from teaching and research institutions in France or abroad, or from public or private research centers.
L'archive ouverte pluridisciplinaire HAL, est destinée au dépôt et à la diffusion de documents scientifiques de niveau recherche, publiés ou non, émanant des établissements d'enseignement et de recherche français ou étrangers, des laboratoires publics ou privés. 


\title{
Half-sandwich nickel(II) NHC-picolyl complexes as catalysts for the hydrosilylation of carbonyl compounds: evidence for NHC- nickel nanoparticles under harsh reaction conditions
}

\author{
Franck Ulm, ${ }^{[a]}$ Saurabh Shahane, ${ }^{[a]}$ Lai Truong-Phuoc, ${ }^{[b]}$ Thierry Romero, ${ }^{[b]}$ \\ Vasiliki Papaefthimiou, ${ }^{[b]}$ Matthieu Chessé, ${ }^{[a]}$ Michael J. Chetcuti, ${ }^{* a]}$ Cuong Pham-Huu, ${ }^{[b]}$ \\ Christophe Michon ${ }^{*[a]}$ and Vincent Ritleng ${ }^{*[a]}$ \\ [a] Dr. F. Ulm, Dr. S. Shahane, Mr. M. Chessé, Pr. M. J. Chetcuti, Dr. C. Michon, Pr. V. Ritleng \\ Université de Strasbourg, Ecole Européenne de Chimie, Polymères et Matériaux, CNRS, LIMA, UMR 7042 \\ 25 rue Becquerel, 67087 Strasbourg, France. \\ E-mail: michael.chetcuti@unistra.fr, cmichon@unistra.fr, vritleng@unistra.fr \\ [b] Dr. L. Truong-Phuoc, Mr. T. Romero, Dr. V. Papaefthimiou, Dr. C. Pham-Huu \\ Université de Strasbourg, Institute of Chemistry and Processes for Energy, Environment and Health (ICPEES), UMR 7515 CNRS \\ 25 rue Becquerel, 67087 Strasbourg, France \\ [c] Dr. C. Pham-Huu, Dr. C. Michon \\ University of Strasbourg Institute for Advanced Study (USIAS) \\ 5 allée du Général Rouvillois, 67083 Strasbourg, France
}

Supporting information for this article is available free of charge on the web.

\begin{abstract}
The cationic [NiCp(Mes-NHC-CH $2 \mathrm{py}] \mathrm{Br}$ complex 2a was prepared directly by the reaction of nickelocene with 1-(2-picolyl)-3mesityl-imidazolium bromide (1), and its $\mathrm{PF}_{6}{ }^{-}$derivative $\mathbf{2} \mathbf{b}$, by subsequent salt metathesis. X-Ray diffraction studies and Variable Temperature ${ }^{1} \mathrm{H}$ NMR experiments run with $\mathbf{2 a}$ and $\mathbf{2} \mathbf{b}$ strongly suggest the bidentate coordination of the picolyl-functionalized carbene to the nickel both in the solid state and in solution in both cases. These data suggest the absence of hemilabile behaviour of the latter, even in the presence of a coordinating anion. Both complexes show similar activity in aldehyde hydrosilylation, further implying the absence of hemilability of the picolyl-functionalized carbene, and effectively reduce a broad scope of aldehydes in the absence of additive under mild conditions. In the case of ketones, effective hydrosilylation is only observed in the presence of a catalytic amount of potassium $t$-butoxide at $100^{\circ} \mathrm{C}$. Dynamic light scattering, scanning transmission electron microscopy and X-ray photoelectron spectroscopy show evidence for the involvement of $\mathrm{NHC}$-picolyl-Ni nanoparticles under these conditions.
\end{abstract}

\section{Introduction}

Hydrosilylation is a reaction of interest for the selective reduction of carbonyl compounds under mild conditions using transitionmetal-based catalysts. ${ }^{[1,2]}$ Indeed, the use of hydrosilanes as reductants, which proceeds without the need of high-pressures or elevated temperatures, is an advantageous surrogate to hydrogenation procedures. As the reactivity of hydrosilanes is modular and depends on their substitution patterns, the hydrosilylation may behave as a highly chemo- and regioselective reduction process that tolerates other reducible functionalities. ${ }^{[2]}$ Beside catalysts based on noble metals, attention has recently turned to catalysts based on earth-abundant $3 \mathrm{~d}$ metals, due to sustainability concerns ${ }^{[3]}$ Among these developed catalysts, ${ }^{[4]}$ half-sandwich $\left[\mathrm{Ni}\left(\eta^{5}-\mathrm{C}_{5} \mathrm{R}_{5}\right) \mathrm{L}(\mathrm{NHC})\right]^{(+)}$complexes have shown interesting activities for the hydrosilylation of carbonyl derivatives. In 2012, some of us reported that [ $\mathrm{NiCpCl}(\mathrm{IMes})] \mathbf{A}\left(\mathrm{Cp}=\eta^{5}-\mathrm{C}_{5} \mathrm{H}_{5}\right.$,
IMes = 1,3-dimesitylimidazol-2-ylidene) effectively catalysed the hydrosilylation of a broad range of aldehydes and ketones at $25^{\circ} \mathrm{C}$ in the presence of $\mathrm{NaHBEt}_{3}$ as a co-catalyst with a turnover frequency (TOF) that reached values up to $390 \mathrm{~h}^{-1}$ for the hydrosilylation of benzaldehyde (Scheme 1). ${ }^{[4]}$ At the same time, Royo et al. described the synthesis of a related half-sandwich nickel(II) complex B bearing a bidentate tetramethylcyclopentadienyl-functionalised carbene ligand, $\left[\mathrm{Ni}\left(\mathrm{Cp}^{*}-\mathrm{NHC}-\mathrm{Me}\right)(\mathrm{OtBu})\right]$, that catalysed the reduction of carbonyl derivatives at temperatures ranging from $25{ }^{\circ} \mathrm{C}$ (aldehydes) to $100^{\circ} \mathrm{C}$ (ketones) with a TOF up to $2300 \mathrm{~h}^{-1}$ for the hydrosilylation of 4-trifluoromethylbenzaldehyde (Scheme 1). ${ }^{[4]]}$ In 2016, Albrecht et al. reported a potentially hemilabile pyridyl-triazolylidene $\mathrm{NiCp}$ precatalyst $\mathbf{C}$ for the hydrosilylation of aldehydes with a TOF as high as $13350 \mathrm{~h}^{-1}$ observed with 4-methoxybenzaldehyde at $60^{\circ} \mathrm{C}$ (Scheme 1)..$^{4 \mathrm{w}]}$

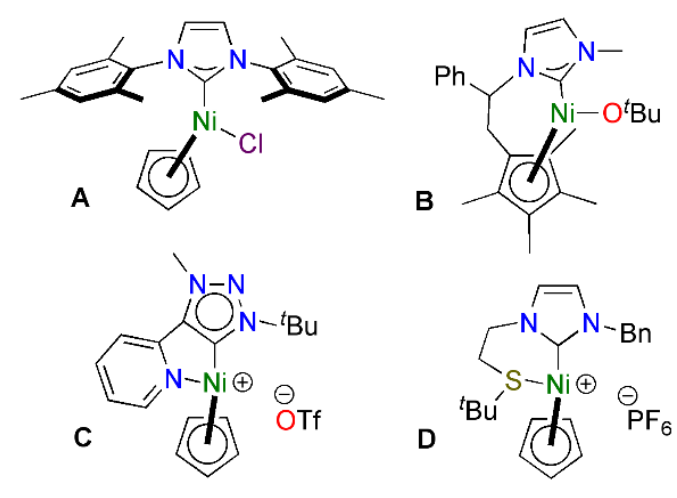

Scheme 1. Previously reported $\left[\mathrm{Ni}\left(\eta^{5}-\mathrm{C}_{5} \mathrm{R}_{5}\right) \mathrm{L}(\mathrm{NHC})\right]^{(+)}$precatalysts for the hydrosilylation of carbonyl compounds.

The high TOF observed with the latter complex was tentatively rationalized as the result a well-balanced hemilabile ligand, with a $\mathrm{C}, \mathrm{N}$-chelate that can both stabilize the catalyst by a strong 
bidentate chelation in the resting state and enable an effective reactivity at the nickel centre by ring opening on the substrate's approach. ${ }^{[\mathrm{w}]}$ The hemilabile balance of chelates may indeed be of utmost importance to develop efficient catalysts. This is especially true for $\left[\mathrm{Ni}\left(\eta^{5}-\mathrm{C}_{5} \mathrm{R}_{5}\right)(\mathrm{NHC}-\mathrm{Y})\right]^{(+)}$complexes, which do not have potentially available coordination site aside from those resulting from decoordination of the Lewis basic $Y$ atom and/or Cp ring slippage from $\eta^{5}$ - to $\eta^{3}$ - or even $\eta^{1}$ - or decoordination. ${ }^{[5,6]}$ Following a recent work in our group on nickel complexes such as D (Scheme 1) bearing hemilabile $\mathrm{K}^{2}-C, S$-thioether-functionalised $\mathrm{NHCs},{ }^{[7]}$ we wondered whether a NHC-picolyl ligand could afford a suitable balance in such type of complexes for nickel-catalysed hydrosilylation reactions.

Herein we describe the synthesis of the cationic [NiCp(Mes$\mathrm{NHC}-\mathrm{CH}_{2}$ py] Br complex bearing a ${ }^{2}-C, N-1-(2-$ picolyl)-3-mesitylimidazol-2-ylidene ligand directly from nickelocene and the corresponding imidazolium bromide. X-Ray diffraction and Variable Temperature (VT) ${ }^{1} \mathrm{H}$ NMR studies strongly suggest the preferential coordination of the pyridine side arm over the bromide anion, both in solution and in the solid state, therefore suggesting no hemilabile behaviour of the picolyl-functionalized carbene ligand. The latter complex and its $\mathrm{PF}_{6}-$ derivative obtained by salt metathesis show similar activity in aldehyde hydrosilylation under mild conditions, which further suggests the absence of hemilabile behaviour. In the case of ketones, the addition $\mathrm{KO}$ tBu to the catalytic medium and a temperature of $100{ }^{\circ} \mathrm{C}$ are requested to observe effective reductions. Diffusion Light Scattering (DLS), Scanning Electron Microscopy in the Transmission mode (SEMT) and X-ray Photoelectron Spectroscopy (XPS) show evidence for the involvement of $\mathrm{NHC}-\mathrm{Ni}$ nanoparticles under these conditions.

\section{Results and Discussion}

Our investigations started with the synthesis of complex $2 \mathrm{a}$ by the reaction of the imidazolium bromide $1^{[8]}$ with nickelocene in THF under reflux (Scheme 2). The use of a conventional oil bath heater resulted in the obtention of $2 \mathrm{a}$ with a $50 \%$ yield after 4 days. Heating through microwave $(2.45 \mathrm{GHz})$ at $110{ }^{\circ} \mathrm{C}$ allowed a substantial reduction in the reaction time, affording $2 a$ in $41 \%$ yield after just $0.5 \mathrm{~h}$. In contrast to what was observed for the reactions of nickelocene with thioether-functionalized imidazo-

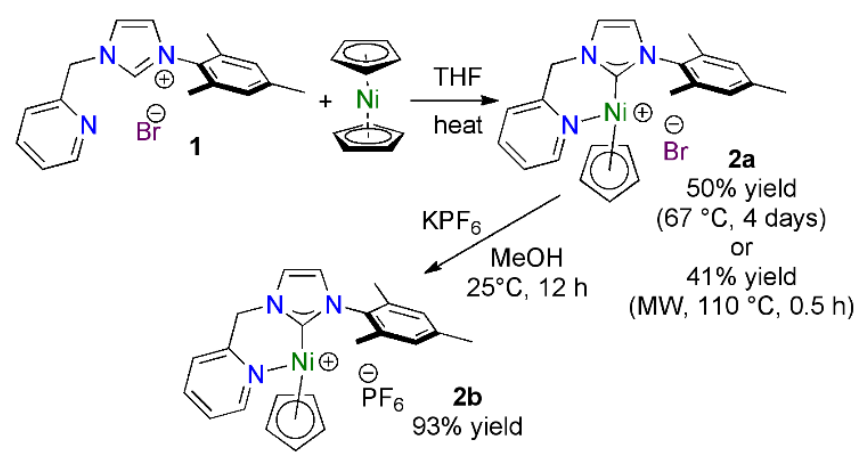

Scheme 2. Synthesis of the cationic NHC-picolyl-Ni(II) complexes $\mathbf{2 a}$ and $\mathbf{2} \mathbf{b}$. lium bromides that yielded neutral complexes bearing monodentate carbenes, ${ }^{[7]}$ the bromide anion was found uncoordinated, and a cationic species bearing a $\mathrm{K}^{2}-\mathrm{C}, \mathrm{N}$-picolyl$\mathrm{NHC}$ ligand was obtained. The subsequent metathesis of $\mathrm{Br}$ to $\mathrm{PF}_{6}$ anion led to complex $\mathbf{2} \mathbf{b}$ with a $93 \%$ yield. It is noteworthy that the synthesis of the $\mathrm{BF}_{4}$ analogue of $\mathbf{2 a}$ and $\mathbf{2 b}$ was recently reported by Valerga et al. through a two-step procedure involving reaction of 1 with $\mathrm{Ag}_{2} \mathrm{O}$ and subsequent transmetalation to nickel by reaction with the air-sensitive $[\mathrm{NiCp}(\mathrm{COD})]\left(\mathrm{BF}_{4}\right) .{ }^{[\mathrm{b}]}$

Single crystals of $\mathbf{2 a}$ and $\mathbf{2 b}$ were obtained at $-28{ }^{\circ} \mathrm{C}$ by diffusion of $n$-pentane in a THF solution of $2 \mathrm{a}$ and by slow solvent evaporation from a solution of $\mathbf{2} \mathbf{b}$ in chloroform. X-ray diffraction studies of $\mathbf{2} \mathbf{a}$ and $\mathbf{2} \mathbf{b}$ established the molecular structures and $\mathrm{k}^{2}$ $\mathrm{C}, \mathrm{N}$-coordination pattern of the 1-(2-picolyl)-3-mesityl-imidazol-2ylidene ligand for both complexes in the solid state (Figures 1, S1S4). Key bond distances and angles are listed in Table 1 and selected crystallographic data and data collection parameters can be found in Table S1.

Complex 2a crystallizes in the orthorhombic space group $\mathrm{P} 2{ }_{1} 2_{1} 2_{1}$. The coordination of the $\mathrm{Ni}$ atom is characterized by a Ni$\mathrm{C}(1)$ bond distance of $1.864 \AA$, a Ni-N(3) distance of $1.922 \AA$ and a Ni-C $p_{\text {cent }}$ distance of $1.751 \AA$ (Table 1) $[\mathrm{C}(1)=$ the carbene carbon atom]. The corresponding $\mathrm{Ni} \cdots \mathrm{Br}$ anion distance is 7.528 $\AA$. Whereas $\mathrm{C}(1)-\mathrm{Ni}-\mathrm{N}(3)$ bite angle is orthogonal with a value of $91.5^{\circ}, \mathrm{C}(1)-\mathrm{Ni}-\mathrm{Cp}_{\text {cent }}$ and $\mathrm{N}(3)-\mathrm{Ni}-\mathrm{Cp}_{\text {cent }}$ angles are larger at $134.6^{\circ}$ and $133.9^{\circ}$, respectively. This is characteristic of $\left[\mathrm{Ni}\left(\eta^{5}\right.\right.$ $\left.\mathrm{C}_{5} \mathrm{R}_{5}\right)(\mathrm{NHC}) \mathrm{L}^{(+)}$type complexes. ${ }^{[5 b, 7,9]}$ One can note however the

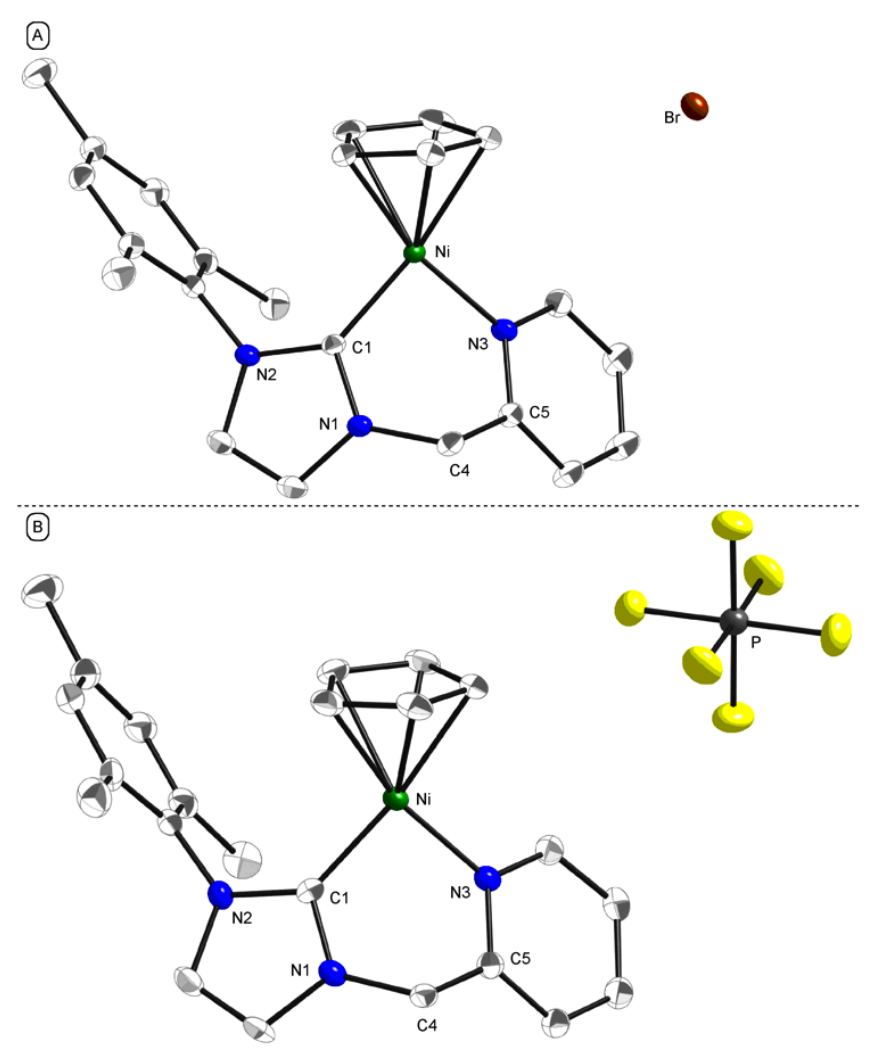

Figure 1. (A) Molecular structure of complex 2a showing all non-H atoms of the cation and one $\mathrm{Br}$ anion. (B) Molecular structure of complex $\mathbf{2 b}$ showing all non-

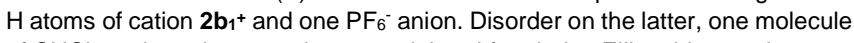
of $\mathrm{CHCl}_{3}$ and another complex were deleted for clarity. Ellipsoids are shown at the $50 \%$ probability level, and key atoms are labelled. ${ }^{[10]}$ 
Table 1. Selected distances $(\AA)$ and angles $\left(^{\circ}\right)$ in $\mathbf{2} \mathbf{a}, \mathbf{2} \mathbf{b}_{1}$ and $\mathbf{2} \mathbf{b}_{\mathbf{2}}$ with esd's in parentheses

\begin{tabular}{llll}
\hline & $\mathbf{2 a}$ & $\mathbf{2 \mathbf { b } _ { 1 }}$ & $\mathbf{2} \mathbf{b}_{\mathbf{2}}$ \\
\hline $\mathrm{Ni}-\mathrm{C}(1)$ & $1.864(3)$ & $1.875(5)$ & $1.875(5)$ \\
$\mathrm{Ni}-\mathrm{N}(3)$ & $1.922(3)$ & $1.930(4)$ & $1.916(4)$ \\
$\mathrm{Ni}-\mathrm{Cp}_{\text {cent }}{ }^{[a]}$ & 1.751 & 1.747 & 1.745 \\
$\mathrm{Ni}-\mathrm{C}_{\mathrm{Cp}}$ av $^{[\mathrm{b}]}$ & 2.124 & 2.119 & 2.121 \\
$\mathrm{C}(1)-\mathrm{Ni}-\mathrm{N}(3)$ & $91.5(1)$ & $92.9(2)$ & $92.2(2)$ \\
$\mathrm{C}(1)-\mathrm{Ni}-\mathrm{Cp} p_{\text {cent }}$ & 134.6 & 133.9 & 133.8 \\
$\mathrm{~N}(3)-\mathrm{Ni}-\mathrm{C} p_{\text {cent }}$ & 133.9 & 133.2 & 133.8 \\
\hline
\end{tabular}

[a] $\mathrm{Cp} p_{\text {cent }}=$ centroid of the $\mathrm{Cp}$ group. [b] Average $\mathrm{Ni}-\mathrm{C}$ distance to the $\mathrm{Cp}$ ring .

relatively smaller $\mathrm{C}(1)-\mathrm{Ni}-\mathrm{N}(3)$ bite angle of $\mathbf{2 a}$ compared to the corresponding $\mathrm{C}(1)-\mathrm{Ni}-\mathrm{S}$ and $\mathrm{C}(1)-\mathrm{Ni}-\mathrm{C}$ angles of the $\mathrm{K}^{2}-C, S$ $\mathrm{NHC}$-thioether complex $\mathbf{D}\left(95.94^{\circ}\right)^{[7]}$ and of a related $\mathrm{K}^{2}-C, C-6$ membered half-sandwich nickelacycle $\left(94.0^{\circ}\right) .{ }^{[9 d]}$ Similar values $\left(89.5-91.7^{\circ}\right)$ were observed in the $\mathrm{NiCp}$ and $\mathrm{NiCp}^{*}\left(\mathrm{Cp}^{*}=\eta^{5}\right.$ $\mathrm{C}_{5} \mathrm{Me}_{5}$ ) complexes described by Valerga et al., bearing closely related $\mathrm{k}^{2}-\mathrm{C}, \mathrm{N}$-picolylimidazol-2-ylidene ligands. ${ }^{[\mathrm{b}]}$

By comparison, complex $\mathbf{2 b}$ crystallizes in the triclinic space

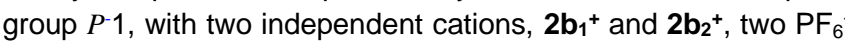
anions and one molecule of chloroform in the crystal unit cell (Figures 1B, S3-S4). The cations $\mathbf{2} \mathbf{b}_{1}{ }^{+}$and $\mathbf{2} \mathbf{b}_{2}{ }^{+}$are not identical having slightly different structural parameters (Table 1) and the fluorine atoms of one $\mathrm{PF}_{6}$ anion exhibit some disorder over two positions. Thus, the coordination of the $\mathrm{Ni}$ atoms in $\mathbf{2} \mathbf{b}_{1}{ }^{+}$and $\mathbf{2} \mathbf{b}_{2}{ }^{+}$ is characterized by the following distances: $\mathrm{Ni}-\mathrm{C}(1)=1.875 / 1.875$ $\AA ̊ \mathrm{Ni}-\mathrm{N}(3)=1.930 / 1.916 \AA$ and Ni-Cp $p_{\text {cent }}=1.747 / 1.745 \AA$ (Table 1). Stronger similarities are noteworthy for the $\mathrm{C}(1)-\mathrm{Ni}-\mathrm{N}(3)$ bite angles with 92.9 and $92.2^{\circ}$, the $\mathrm{C}(1)-\mathrm{Ni}-\mathrm{Cp}_{\text {cent }}$ angles with 133.9 and $133.8^{\circ}$ and the $\mathrm{N}(3)-\mathrm{Ni}-\mathrm{C} p_{\text {cent }}$ angles with 133.2 and $133.8^{\circ}$, respectively.

The main spectroscopic features of $\mathbf{2} \mathbf{a}, \mathbf{b}$ are in agreement with their X-ray structures. The carbene carbon is observed at $c a$. $162 \mathrm{ppm}$ in the ${ }^{13} \mathrm{C}$ NMR $\left(\mathrm{CDCl}_{3}\right)$ spectra while the $\mathrm{Cp}$ carbons appear at ca. $92.5 \mathrm{ppm}$. In the ${ }^{1} \mathrm{H}$ NMR spectra, the Cp protons of $\mathbf{2 a}$ and $\mathbf{2 b}$ resonate as a singlet at $4.99 \mathrm{ppm}$ in both cases. However, in contrast to what is expected in the case of a chelate, the ${ }^{1} \mathrm{H}$ NMR spectrum of $\mathbf{2 a}$ at room temperature (RT) exhibits a broad singlet at $6.32 \mathrm{ppm}$ that integrates for two protons for the methylene protons. Similarly, the ${ }^{1} \mathrm{H}$ NMR spectrum of $\mathbf{2} \mathbf{b}$ at RT shows these protons as a singlet integrating for two protons, however as a sharper and slightly more shielded (5.68 ppm) peak in this case. These surprising observations suggested the existence of a dynamic process in solution at RT in both complexes. VT ${ }^{1} \mathrm{H}$ NMR experiments were then performed on $\mathrm{CD}_{2} \mathrm{Cl}_{2}$ solutions of $\mathbf{2 a}$ and $\mathbf{2} \mathbf{b}$ between 298 and $203 \mathrm{~K}$ to check if these dynamic processes could be frozen on the NMR time scale at low temperature. In the case of $\mathbf{2 a}$, the singlet of the $\mathrm{NCH}_{2}$ py methylene group that is observed at $5.56 \mathrm{ppm}$ at $298 \mathrm{~K}$ in $\mathrm{CD}_{2} \mathrm{Cl}_{2}$ broadens as the temperature decreases and decoalesces between 213 and $208 \mathrm{~K}$ to give two very broad signals integrating for one proton each at 5.47 and $5.43 \mathrm{ppm}$ at $203 \mathrm{~K}$. The free energy of activation $\left(\Delta G^{\ddagger}\right)$ for this process, based on this (de)coalescence temperature of the $\mathrm{NCH}_{2}$ py group (ca. $210 \mathrm{~K}$ ) is of ca. $16 \mathrm{kcal} \mathrm{mol}^{-1}{ }^{[11]}$ In contrast, no decoalescence could be observed for $\mathbf{2} \mathbf{b}$, indicating a fast dynamic process involving the $\mathrm{NCH}_{2}$ py arm on the NMR time scale. Considering the weak coordinating ability of the $\mathrm{PF}_{6}{ }^{-}$anion, it is unlikely that the latter can displace the pyridine group from the nickel centre. Thus, it is reasonable to postulate that the absence of diastereotopy observed for $\mathbf{2} \mathbf{b}$, even at low temperature, is likely due to small angle oscillations about the $\mathrm{N} 3-\mathrm{Ni}$ and $\mathrm{N} 1-\mathrm{C} 1$ bonds, and/or to conformational isomerization of the "chair-boat" type as proposed by Valerga et al. for closely related $\mathrm{k}^{2}-\mathrm{C}, \mathrm{N}-\left[\mathrm{Ni}\left(\eta^{5}-\mathrm{C}_{5} \mathrm{R}_{5}\right)(\mathrm{Ar}-\mathrm{NHC}\right.$ $\left.\left.\mathrm{CH}_{2}-\mathrm{Py}\right)\right]\left(\mathrm{BF}_{4}\right)$ complexes. In the case of $\mathbf{2 a}$, a similar process most probably occurs as the decoalescence of the methylene signal observed at low temperature strongly suggest the coordination of the pyridyl group to the nickel centre in solution as well. ${ }^{[12]}$ This assumption is further corroborated by the green colour of the solution, characteristic of cationic $\left[\mathrm{Ni}\left(\mathrm{n}^{5}\right.\right.$ $\left.\left.\mathrm{C}_{5} \mathrm{R}_{5}\right) \mathrm{L}(\mathrm{NHC})\right]^{+} \mathrm{X}$-complexes, ${ }^{[7,12]}$ as well as by the chemical shift of the pyridine nitrogen atom at $217 \mathrm{ppm}$ in the ${ }^{15} \mathrm{~N}$ NMR spectrum of $2 \mathbf{a}$ at $298 \mathrm{~K}$ (Figure S5), characteristic of pyridine nitrogen atom coordination to a metal centre. ${ }^{[13]}$

Complexes 2a,b were subsequently applied as catalysts for the reduction of benzaldehyde $\mathbf{3} \mathbf{a}$ to benzylic alcohol $\mathbf{4 a}$ through hydrosilylation using solely phenyl silane, and subsequent basic hydrolysis (Scheme 3). At a loading of 2 mol\% under mild reaction conditions (e.g. $4 \mathrm{~h}$ at $40^{\circ} \mathrm{C}$ ), complexes $\mathbf{2 a}$ and $\mathbf{2 b}$ both allowed the effective reduction of $\mathbf{3 a}$ into $\mathbf{4 a}$ with a similar yield of $92 \%$, thus showing no difference of reactivity despite the different coordinating ability of their respective counter-ions.

The substrate scope of the reaction was then explored investigating the hydrosilylation of substituted benzaldehydes $3 \mathbf{b}$ $\mathbf{g}$ to the corresponding alcohols $\mathbf{4 b - g}$ (Scheme 3 ). By using $\mathbf{2} \mathbf{a}$ as catalyst and similar conditions, these reactions also proceeded in high yields independently of the electron-donor or

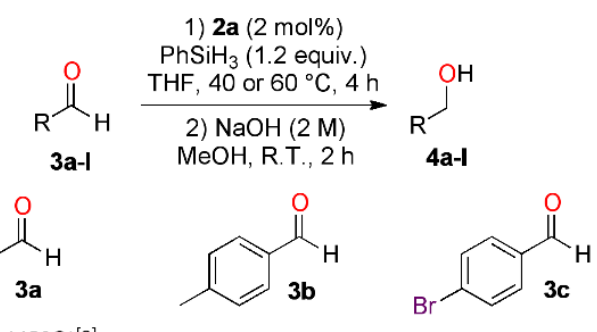

$$
\text { 4a } 92 \% \text { yield }\left(40^{\circ} \mathrm{C}\right)^{[a]} \quad \mathbf{4 b} 100 \% \text { yield }\left(40^{\circ} \mathrm{C}\right) \quad \mathbf{4 c} 98 \% \text { yield }\left(60^{\circ} \mathrm{C}\right)
$$<smiles>COc1ccc(C=O)cc1</smiles>

4d $95 \%$ yield $\left(60^{\circ} \mathrm{C}\right)$<smiles>CC(=O)c1ccc(C=O)cc1</smiles>

$4 \mathrm{~g} 98 \%$ yield $\left(40^{\circ} \mathrm{C}\right)$<smiles>O=C/C=C/c1ccccc1</smiles>

4j $64 \%$ yield $\left(40^{\circ} \mathrm{C}\right)$<smiles>CN(C)c1ccc(C=O)cc1</smiles>

4e $100 \%$ yield $\left(40^{\circ} \mathrm{C}\right)$<smiles>O=Cc1cccc2ccccc12</smiles>

4h $67 \%$ yield $\left(40^{\circ} \mathrm{C}\right)$<smiles>O=CCCc1ccccc1</smiles>

4k $62 \%$ yield $\left(60^{\circ} \mathrm{C}\right)$<smiles>N#Cc1ccc(C=O)cc1</smiles>

4f $98 \%$ yield $\left(40^{\circ} \mathrm{C}\right)$

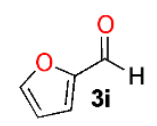

4i $90 \%$ yield $\left(60^{\circ} \mathrm{C}\right)$

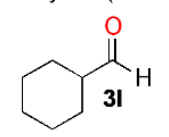

$4167 \%$ yield $\left(60^{\circ} \mathrm{C}\right)$
Scheme 3. Hydrosilylation of aldehydes $3 a-1$ to alcohols $4 a-1$ using catalyst 2 a NMR yields (\%). [a] Same result using catalyst $\mathbf{2 b}$. 
-acceptor character of the substituents. It is worth noting that substrates $\mathbf{3 c}$ and $\mathbf{3 d}$ bearing bromo or methoxy groups required heating to $60{ }^{\circ} \mathrm{C}$ in order to proceed smoothly. Interestingly, the hydrosilylation of aldehydes $\mathbf{3} \mathbf{f}$ and $\mathbf{3 g}$ proceeded chemoselectively, the nitrile and ester functions being not reduced. In addition, 1-naphtaldehyde $\mathbf{3 h}$ and furan-2carbaldehyde $\mathbf{3 i}$ were effectively converted to the corresponding alcohols in $67 \%$ and $90 \%$ yields, respectively (Scheme 3 ). Finally, the hydrosilylation of 31 proceeded at $40{ }^{\circ} \mathrm{C}$ with a $64 \%$ yield and without any reduction of the conjugated $\mathrm{C}-\mathrm{C}$ double bond. By comparison, the reaction of alkyl aldehydes $\mathbf{3} \mathbf{k}$ and $\mathbf{3} \mathbf{l}$ required a $60^{\circ} \mathrm{C}$ heating in order to afford similar yields.

We next focused our attention on the catalytic activity of complexes $\mathbf{2 a , b}$ for the hydrosilylation of acetophenone $\mathbf{5 a}$ (Table 2). By using similar reaction conditions as for the reduction of aldehydes (e.g. $40^{\circ} \mathrm{C}, 4 \mathrm{~h}$ ), the catalysts $2 \mathbf{a}, \mathbf{b}$ again showed a similar activity, leading to the corresponding alcohol $\mathbf{6 a}$ in a similar $16 \%$ yield (entries $1-2$ ). The latter was slightly increased to $25 \%$ by heating at $60{ }^{\circ} \mathrm{C}$ for $19 \mathrm{~h}$ (entry 3). In order to check the effect of the counter-anion and various additives on the catalysis, ${ }^{[14]}$ an anion screening was carried out (entries 4-10). Apart from acetate that led to a $21 \%$ yield for $6 \mathrm{a}$ after $4 \mathrm{~h}$ reaction at $40^{\circ} \mathrm{C}$ (entry 10 ), none of the $\mathrm{BArF}_{24}{ }^{-}$(tetrakis[(3,5-

Table 2. Reaction conditions optimization for the hydrosilylation of acetophenone $\mathbf{5} \mathrm{a}^{[\mathrm{a}]}$

\begin{tabular}{|c|c|c|c|c|c|c|}
\hline \multirow[b]{3}{*}{ Ent. } & \multirow{3}{*}{$\frac{5 a}{\text { Cat. }}$} & \multicolumn{4}{|c|}{$\begin{array}{l}\text { 1) } \mathbf{2} \mathbf{a} \text { or } \mathbf{2 b}(2 \mathrm{~mol} \%) \text {, additive }(2-4 \mathrm{~mol} \%) \\
\mathrm{PhSiH}_{3}\left(1.2 \text { equiv.), solvent, } \mathrm{T}\left({ }^{\circ} \mathrm{C}\right), \mathrm{t}(\mathrm{h})\right.\end{array}$} & \multirow{2}{*}{${ }_{\mathbf{a}}^{\mathrm{OH}}$} \\
\hline & & \multicolumn{3}{|c|}{$\begin{array}{l}\text { 2) } \mathrm{NaOH}(2 \mathrm{M}) \\
\mathrm{MeOH}, 2 \text { h, R.T. }\end{array}$} & $\mathrm{Ph}_{6 \mathrm{a}}$ & \\
\hline & & Solvent & $\begin{array}{l}\text { Additive } \\
\text { (mol\%) }\end{array}$ & $\begin{array}{l}\mathrm{T} \\
\left({ }^{\circ} \mathrm{C}\right)\end{array}$ & $\begin{array}{l}\text { Time } \\
\text { (h) }\end{array}$ & $\begin{array}{l}\text { Yield } \\
(\%)^{[b]}\end{array}$ \\
\hline 1 & $2 a$ & THF & - & 40 & 4 & 16 \\
\hline 2 & $2 b$ & THF & - & 40 & 4 & 16 \\
\hline 3 & $2 a$ & THF & - & 60 & 19 & 25 \\
\hline 4 & $2 a$ & THF & $\mathrm{NaSbF}_{6}(2)$ & 40 & 4 & 6 \\
\hline 5 & $2 a$ & THF & $\mathrm{NaBArF}_{24}(2)$ & 40 & 4 & 6 \\
\hline 6 & $2 a$ & THF & $\mathrm{KBArF}_{24}(2)$ & 40 & 4 & 1 \\
\hline 7 & $2 a$ & THF & $\mathrm{NBu}_{4} \mathrm{OTf}(2)$ & 40 & 4 & 1 \\
\hline 8 & $2 a$ & THF & $\mathrm{KNTf}_{2}(2)$ & 40 & 4 & 7 \\
\hline 9 & $2 a$ & THF & Kacac (4) & 40 & 4 & 10 \\
\hline 10 & $2 a$ & THF & KOAc (4) & 40 & 4 & 21 \\
\hline 11 & $2 a$ & THF & KOAc (4) & 60 & 19 & 38 \\
\hline 12 & $2 a$ & THF & $\mathrm{KOtBu}(2)$ & 40 & 4 & 15 \\
\hline 13 & $2 a$ & THF & $\mathrm{KOtBu}(2)$ & 60 & 19 & 47 \\
\hline 14 & 2a & Toluene & $\mathrm{KOtBu}(2)$ & 60 & 19 & 49 \\
\hline 15 & $2 a$ & Toluene & $\mathrm{KOtBu}(2)$ & 100 & 19 & $74^{[\mathrm{c}]}$ \\
\hline 16 & $2 a$ & Toluene & $\mathrm{KOtBu}(2)$ & 100 & 24 & 96 \\
\hline
\end{tabular}

[a] Experiments run on a $0.25 \mathrm{mmol}$ acetophenone scale. [b] Isolated yields after hydrolysis. [c] $22 \%$ yield without $\mathrm{KO}$ tBu additive. trifluoromethyl)phenyl]borate), $\mathrm{SbF}_{6}^{-}, \mathrm{OTf}^{-}, \mathrm{NTf}_{2}^{-}$or acac anions afforded a better yield than 2a,b without additives (entries 4-9). An increase of the reaction temperature to $60^{\circ} \mathrm{C}$ and time to $19 \mathrm{~h}$ resulted in a $38 \%$ yield of $6 \mathrm{a}$ with KOAc (entry 11 ). A similar trend was observed with $\mathrm{KO}$ tBu as additive (entries 12 and 13), ${ }^{[4,15,16]}$ but a higher yield of $47 \%$ yield was obtained (entry 13 ), though this additive effect was not significant at $40{ }^{\circ} \mathrm{C}$ (entry 12). A change of solvent to toluene allowed a further increase of the reaction temperature to $100{ }^{\circ} \mathrm{C}$ and afforded benzyl alcohol $6 \mathbf{a}$ with a $74 \%$ yield in $19 \mathrm{~h}$ and an almost quantitative $96 \%$ yield in $24 \mathrm{~h}$ (entries 14-16).

With these conditions in hand, the substrate scope of the reaction was then explored by investigating the hydrosilylation of various aryl and alkyl ketones 5a-I into the corresponding alcohols 6a-I (Scheme 4). Though the hydrosilylation of acetophenone 5a and benzophenone $\mathbf{5 b}$ proceeded in high yields, the reduction of propiophenone $\mathbf{5 c}$ proved to be harder, a reaction time of $61 \mathrm{~h}$ being required in order to reach $74 \%$ yield. Moreover, the hydrosilylation of more sterically hindered ketones was limited. ${ }^{[17]}$ Indeed, the reductions of 2-methyl-1-phenylpropan-1-one $\mathbf{5 d}$, dicyclohexylmethanone $\mathbf{5 e}$ and 2-acetylmesitylene $\mathbf{5 f}$ led to much lower yields. Furthermore, it is worth noting that the hydrosilylation of the conjugated ketone, 4-phenylbut-3-en-2-one $\mathbf{5 g}$, proceeded with $75 \%$ yield in $24 \mathrm{~h}$ and implied the reduction of both the carbonyl and the conjugated $\mathrm{C}-\mathrm{C}$ double bond, thus leading to the saturated alcohol $\mathbf{6 h}$. By comparison, the reduction of 4phenylbutan-2-one $5 \mathrm{~h}$ led to $\mathbf{6 h}$ in a similar yield. The hydrosilylation of cyclohexanone $\mathbf{5 i}$ afforded the corresponding cyclohexanol $6 \mathbf{i}$ in $57 \%$ yield after $24 \mathrm{~h}$ reaction, but an extended reaction time to $61 \mathrm{~h}$ resulted in $92 \%$ yield. The reduction of other cyclic ketones $5 \mathbf{j}-\mathbf{I}$ comprising an additional aromatic proceeded in moderate to good yields.

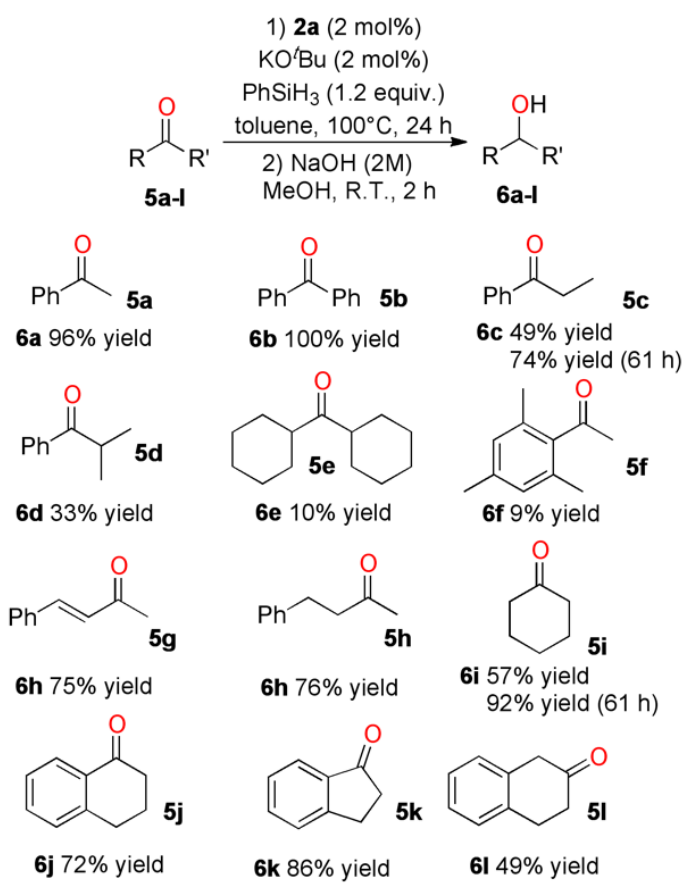

Scheme 4. Hydrosilylation of ketones 5 a-I into alcohols 6 a-I using catalyst $\mathbf{2 a}$ GC yields (\%) 
Regarding the activation effect of $\mathrm{KO} \mathrm{Bu}^{[15,16,18]}$ and the reaction mechanism at play in these ketones' hydrosilylations, it is of interest that the reductions of $\mathbf{5 a - I}$ were characterized by a striking colour change from clear brown to deep black within a few minutes (Figures S6 and S7). To gain some insight into the nature of the active species, we prepared a toluene- $d_{8}$ solution comprising complex 2a (2 mol\%), KOtBu (2 mol\%) and phenylsilane, but without the ketone reagent, and heated up to $100{ }^{\circ} \mathrm{C}$ for $1 \mathrm{~h}$. The same colour change was observed. After cooling the reaction medium to room temperature, a sample was placed in a sealed tube and analysed by ${ }^{1} \mathrm{H}$ and ${ }^{29} \mathrm{Si}$ NMR spectroscopy. The resulting ${ }^{1} \mathrm{H}$ NMR spectrum did not show any hydride intermediate ${ }^{[4 e, 18,19]}$ nor any $[\mathrm{Ni}(\mathrm{I}) \mathrm{Cp}(\mathrm{NHC})]^{[18,20]}$ or other well-defined $\mathrm{Ni}$ species, and further interpretations proved to be difficult. The ${ }^{29} \mathrm{Si}$ NMR spectrum did not allow us to observe the pentacoordinate siliconate species, $\left[\mathrm{PhSiH}_{3}(\mathrm{OtBu})\right]^{-}\left(\right.$at $\delta^{29} \mathrm{Si}=-$ $96.2 \mathrm{ppm}$ ), that was reported by Thomas et al. to act as an in situ generated universal reducing species of a relatively wide range of pre-catalysts of $\mathrm{Fe}(\mathrm{II}), \mathrm{Co}$ (II) and $\mathrm{Mn}$ (II) for hydrosilylation reactions when $\mathrm{NaO}$ tBu was used as an activator in conjunction with $\mathrm{PhSiH}_{3}{ }^{[15]}$

Despite the change of colour to deep black, the course of the catalytic reduction of acetophenone under the conditions of Scheme 4 remained unchanged when performing a hot filtration test after $19 \mathrm{~h}$ reaction, and similarly afforded $6 \mathbf{a}$ in $96 \%$ yield after $24 \mathrm{~h}$ reaction. Furthermore analyses of both a sample of $\mathbf{2 a}$ (2 mol\%), $\mathrm{KOtBu}(2 \mathrm{~mol} \%)$ and $\mathrm{PhSiH}_{3}$ and a sample of $\mathbf{2 a}(2 \mathrm{~mol} \%)$ and $\mathrm{PhSiH}_{3}$, prepared in toluene at $100{ }^{\circ} \mathrm{C}$, by GC-MS and IR spectroscopy showed no evidence of $\mathrm{NHC}$ ligand degradation to the corresponding azolone (Figures S8-S14), therefore allowing us to rule out an Ananikov type activation/deactivation mechanism. ${ }^{[16]}$ Nevertheless, when we performed a measurement by $\mathrm{DLS}^{[21]}$ on a similar sample of $2 \mathrm{a}(2 \mathrm{~mol} \%)$, $\mathrm{KOtBu}(2 \mathrm{~mol} \%)$ and $\mathrm{PhSiH}_{3}$ prepared in toluene at $100{ }^{\circ} \mathrm{C}$, we observed a fine distribution of particles of ca. $310 \mathrm{~nm}$ wide (Figure S15). To establish whether these particles were generated by the combined action of $\mathrm{PhSiH}_{3}$ and $\mathrm{KOtBu}$ at $100^{\circ} \mathrm{C}$ or the sole action of $\mathrm{PhSiH}_{3}$ at this temperature, we next prepared a sample from complex 2a and $\mathrm{PhSiH}_{3}$ in toluene under similar conditions, but without addition of $\mathrm{KOtBu}$. DLS indicated the presence of nanoparticles of average $90 \mathrm{~nm}$ sizes in this case (Figures S16). However, these nanoparticles proved to be relatively ineffective for the hydrosilylation of acetophenone $\mathbf{5 a}$ compared to the particles generated in the presence of $\mathrm{KO}$ tBu $(22 \%$ yield after 19 $\mathrm{h}$ at $100{ }^{\circ} \mathrm{C}$ vs. $74 \%$ yield in the presence of $\mathrm{KO} t \mathrm{Bu}$, see Table 2 , entry 15).

Afterwards, we evaporated a DLS sample of $\mathbf{2 a}(2 \mathrm{~mol} \%)$, $\mathrm{KOtBu}(2 \mathrm{~mol} \%)$ and $\mathrm{PhSiH}_{3}$ prepared in toluene at $100{ }^{\circ} \mathrm{C}$ on a glass support in an argon filled glovebox; the remaining oily solid residue was subsequently analysed by X-ray diffraction (XRD) in the reflexion mode (Figures S17 and S18). Most of the observed diffractions were fitted with the diffraction patterns of $\mathrm{KBr}$. Such a result can be attributed to the poor crystallinity of the sample. This rendered the observation of $\mathrm{NiO}$ (most probably formed after air exposure) difficult, and there was no evidence for the presence of $\mathrm{Ni}(111)$, e.g. $\mathrm{Ni}(0)$ species. However, XRD is mainly a bulk technique, which is hardly accurate for the analysis of such small and dispersed samples.

Two similar samples, one fresh and one aged, were then analysed by XPS in order to determine the chemical composition at the topmost surface (i.e.: $9 \pm 2 \mathrm{~nm}$ ) of the catalysts. The survey scan and high-resolution spectra of the freshly prepared sample revealed the core levels of $\mathrm{C} 1 \mathrm{~s}, \mathrm{O} 1 \mathrm{~s}, \mathrm{~N} 1 \mathrm{~s}, \mathrm{Ni} 2 \mathrm{p}, \mathrm{Br} 3 \mathrm{~d}$ and Si2p elements (Figures S19 and S20). More specifically, the peaks values for $\mathrm{Ni2} \mathrm{p}_{3 / 2}$ and $2 \mathrm{p}_{3 / 2}$ satellite of the $\mathrm{Ni} 2 \mathrm{p}$ region are found at 853.6 and ca. $861.7 \mathrm{eV}$, respectively (Figure 2, red). These values are consistent with the presence of $\mathrm{NiO}$, which could result from the oxidation of the $\mathrm{Ni}(0)$ species during the transport of the sample in air, as observed by XRD. However, it is worthy to note that, due to the weak signal-to-noise ratio, the assignment of the $\mathrm{Ni}(0)$ vs. $\mathrm{Ni}(2+)$ is not straightforward, and the presence of some residual $\mathrm{Ni}(0)$ cannot be completely ruled out in this sample (Figures S20 and S21). ${ }^{[22]}$ Raman spectroscopy, carried out on a sample whose exposure to air was avoided, indeed showed no evidence of $\mathrm{Ni}$ oxides $\left(150-430 \mathrm{~cm}^{-1}\right)$ and $\mathrm{Ni}$ hydroxides (3100$3650 \mathrm{~cm}^{-1}$ ) (Figure S22).

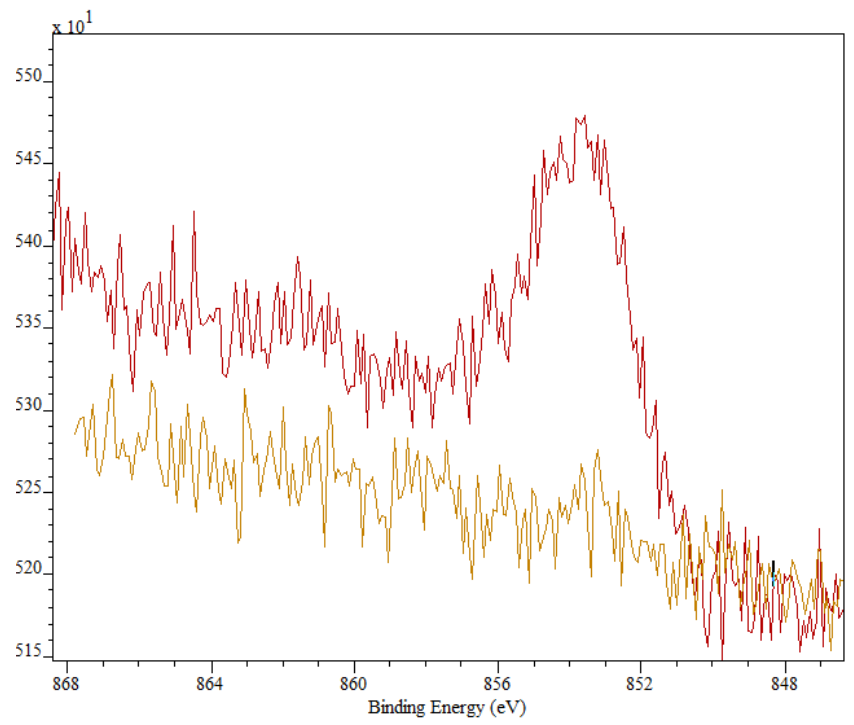

Figure 2. XPS spectra of Ni 2p3/2. Red: fresh sample; orange: aged sample.

Interestingly, no Ni was detected by XPS in the aged sample (Figure 2, orange), suggesting the progressive agglomeration of the nanoparticles (filtration onto $200 \mathrm{~nm}$ PTFE filters was carried out before analysis), and thus their instability. Furthermore, the $\%$ surface ratio of all the elements confirmed the presence of $\mathrm{C}, \mathrm{O}$, $\mathrm{N}, \mathrm{Si}, \mathrm{Br}$ and $\mathrm{Ni}$ elements in the fresh sample and the $\mathrm{Ni} / \mathrm{N}$ ratio of $1: 4$ suggested the presence of NHC-picolyl-coordinated $\mathrm{Ni}$ particles. As expected, the old sample contained only $\mathrm{C}, \mathrm{O}, \mathrm{N}$ and Si elements (Table S3).

Evaporation in an argon filled glovebox of a similar sample of 2a (2 mol\%), KOtBu (2 mol\%) and $\mathrm{PhSiH}_{3}$ on a membrane support allowed analyses by SEM and SEM-T microscopies. Some faceted particles with a dimension of ca. 200 to $600 \mathrm{~nm}$ were observed which could be attributed to the Ni-based material (Figures 3 and S22). SEM-EDX chemical analysis confirmed that the observed particles were comprised of $\mathrm{C}, \mathrm{N}, \mathrm{O}, \mathrm{Ni}, \mathrm{Br}$ and $\mathrm{Si}$ elements, at least on their surface (Figure S23, Table S3). To get further insight into the bulk composition of these $310 \mathrm{~nm}$ particles and get a reliable estimation of the number of $\mathrm{NHC}$-picolyl ligands that remain bound to the nickel, two samples were then analysed by ICP-AES and CHN elemental analyses. Mass percentages of $6.3 \pm 0.2(\mathrm{Ni})$ and $3.16 \pm 0.4(\mathrm{~N})$ were measured, which corresponds to a Ni:N molar ratio of 1:2, thus to a Ni:NHC ratio of 1.5:1. These results confirm the coordination of NHC-picolyl 
ligands to the Ni nanoparticles and highlight, to the best of our knowledge, only the third example of NHC stabilized nanoparticles. ${ }^{[23,24]}$

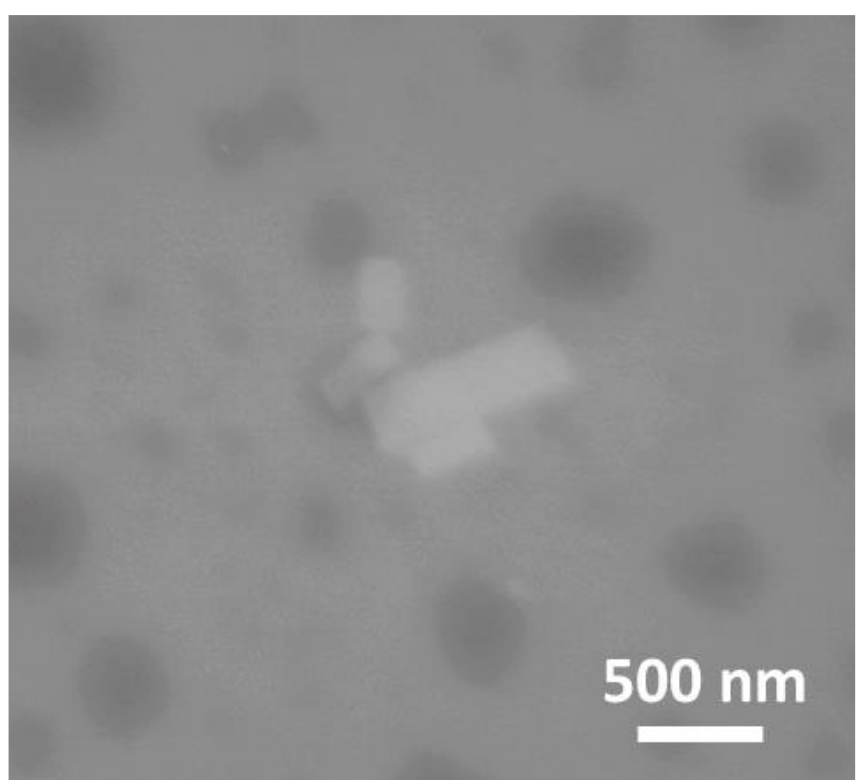

Figure 3. MEB-STEM image of Ni NHC-picolyl nanoparticles.

\section{Conclusion}

In this work, we have shown that an accessible cationic halfsandwich $\mathrm{Ni}(\mathrm{II})-\mathrm{NHC}$-picolyl complex $\mathbf{2 a}$ bearing a bromide counter-ion effectively catalyzes the hydrosilylation of a broad range of aldehydes without additive and of ketones in the presence of $\mathrm{KOtBu}$ at $100{ }^{\circ} \mathrm{C}$. Single-crystal and VT ${ }^{1} \mathrm{H}$ NMR studies tend to show the absence of a hemilability of the picolylfunctionalized carbene ligand. Studies by DLS, transmission mode SEM, XPS, ICP-AES and CHN elemental analyses showed evidence for the involvement of NHC-picolyl $\mathrm{Ni}$ particles in the catalytic reactions when $\mathrm{KO}$ tBu is used as an additive. Though $\mathrm{KOtBu}$ clearly acts has an activator leading to the formation of catalytically active particles, together with $\mathrm{PhSiH}_{3}$, their detailed implication in this process remains unclear. Further studies on such NHC-stabilized-Ni nanocatalysts are currently in progress in our laboratories and will be reported in the future.

\section{Experimental Section}

\section{Synthesis of [NiCp $\left.\left\{\mathrm{Bn}-\mathrm{NHC}-\left(\mathrm{CH}_{2}\right)-\mathrm{Py}\right\}\right](\mathrm{Br})(2 \mathrm{a})$}

A $10 \mathrm{~mL}$ vial containing a stirring bar was charged with nickelocene $(106$ $\mathrm{mg}, 0.561 \mathrm{mmol}), 1$-mesityl-3-(2-picolyl)imidazolium bromide 1 (200 mg $0.558 \mathrm{mmol})$, and THF ( $5 \mathrm{~mL})$. After sealing the vial, the green suspension was heated at $110^{\circ} \mathrm{C}$ for $0.5 \mathrm{~h}$ in a Discover CEM S-class microwave operating at $2.45 \mathrm{GHz}$. The resulting suspension was filtered through a Celite pad that was washed with THF $(3 \times 10 \mathrm{~mL})$. The solvent was then removed under vacuum, and the resulting residue triturated in pentane (5 $\mathrm{mL}$ ) to afford 2a as a green powder after solvent removal with a syringe and vacuum drying (109 $\mathrm{mg}, 0.223 \mathrm{mmol}, 41 \%$ yield). Anal. calcd for $\mathrm{C}_{23} \mathrm{H}_{24} \mathrm{BrN}_{3} \mathrm{Ni}$ : C, $57.43 ; \mathrm{H}, 5.03$; N, 8.74; found: C, 57.12; H, 4.96; N, 8.81 . ESI-MS (TOF): $\mathrm{m} / \mathrm{z} 400.1318$ calcd. for $\mathrm{C}_{23} \mathrm{H}_{24} \mathrm{~N}_{3} \mathrm{Ni}[\mathrm{M}-\mathrm{Br}]^{+}, 400.1318$, found 400.1298. ${ }^{1} \mathrm{H} \mathrm{NMR}\left(\mathrm{CDCl}_{3}, 300 \mathrm{MHz}\right): \delta 8.61(\mathrm{~s}, 1 \mathrm{H}, \mathrm{NCH}), 8.51$ (br. $\mathrm{d},{ }^{3} \mathrm{~J}=7.5,1 \mathrm{H}, 3-$ or $\left.6-\mathrm{H}_{\mathrm{Py}}\right), 8.30\left(\mathrm{~d},{ }^{3} \mathrm{~J}=5.4,1 \mathrm{H}, 3-\right.$ or $\left.6-\mathrm{HPy}_{\mathrm{Py}}\right), 7.84$ (t, ${ }^{3} J=7.5,1 \mathrm{H}, 4-$ or $\left.5-\mathrm{H}_{\mathrm{Py}}\right), 7.08\left(\mathrm{t},{ }^{3} \mathrm{~J}=5.1,1 \mathrm{H}, 4-\right.$ or $\left.5-\mathrm{H}_{\mathrm{Py}}\right), 7.05(\mathrm{~s}, 2 \mathrm{H}, \mathrm{m}$ $\left.\mathrm{H}_{\text {Mes }}\right), 6.75(\mathrm{~s}, 1 \mathrm{H}, \mathrm{NCH}), 6.32\left(\mathrm{~s}, 2 \mathrm{H}, \mathrm{CH}_{2}\right), 4.99\left(\mathrm{~s}, 5 \mathrm{H}, \mathrm{C}_{5} \mathrm{H}_{5}\right), 2.39(\mathrm{~s}, 3 \mathrm{H}$
$\left.p-\mathrm{CH}_{3}\right), 2.03\left(\mathrm{~s}, 6 \mathrm{H}, o-\mathrm{CH}_{3}\right) \cdot{ }^{13} \mathrm{C}\left\{{ }^{1} \mathrm{H}\right\} \mathrm{NMR}\left(\mathrm{CDCl}_{3}, 75 \mathrm{MHz}\right): \delta 161.0(\mathrm{NCN})$ 158.3 (3-Сpy), 157.1 (1-Сpy), 140.1 (ipso-- Mes), 139.4 (5-Сpy), 135.6 (p-

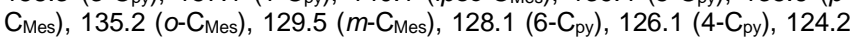
$(\mathrm{NCH}), 122.9(\mathrm{NCH}), 92.4\left(\mathrm{C}_{5} \mathrm{H}_{5}\right), 53.8\left(\mathrm{CH}_{2}\right), 21.3\left(p-\mathrm{CH}_{3}\right), 18.2\left(o-\mathrm{CH}_{3}\right)$.

\section{Synthesis of [NiCp $\{\mathrm{Bn}-\mathrm{NHC}-(\mathrm{CH} 2)-\mathrm{Py}\}]\left(\mathrm{PF}_{6}\right)(2 \mathrm{~b})$}

An oven dried Schlenk tube containing a stirring bar was loaded with $2 \mathrm{a}$ (300 mg, $0.624 \mathrm{mmol}$ ), $\mathrm{KPF}_{6}(0.115 \mathrm{mg}, 0.625 \mathrm{mmol}$ ) and THF (4 mL). The resulting green suspension was stirred at room temperature overnight and at $40{ }^{\circ} \mathrm{C}$ for $40 \mathrm{~min}$. The reaction medium was then cooled to room temperature and its contents filtered over a pad of Celite that was washed with THF until the solvent went colourless. The filtrate was evaporated to dryness to give $\mathbf{2 b}$ as a green powder (338 $\mathrm{mg}, 0.619 \mathrm{mmol}, 93 \%$ yield). Anal. calcd for $\mathrm{C}_{23} \mathrm{H}_{24} \mathrm{~F}_{6} \mathrm{~N}_{3} \mathrm{NiP}+1 / 2 \mathrm{C}_{4} \mathrm{H}_{8} \mathrm{O}$ : C, 51.57; $\mathrm{H}, 4.85 ; \mathrm{N}, 7.22$ found: C, 51.48; H, 5.01; N, 6.95. ESI-MS (TOF): m/z 400.1318 calcd. for $\mathrm{C}_{23} \mathrm{H}_{24} \mathrm{~N}_{3} \mathrm{Ni}\left[\mathrm{M}-\mathrm{PF}_{6}\right]^{+}$, found 400.1310. ${ }^{1} \mathrm{H} \mathrm{NMR}\left(\mathrm{CDCl}_{3}, 300 \mathrm{MHz}\right): \delta 8.36$ $\left(\mathrm{d},{ }^{3} \mathrm{~J}=5.7,1 \mathrm{H}, 3-\mathrm{H}_{\mathrm{Py}}\right), 7.89\left(\mathrm{~m}, 1 \mathrm{H}, 4-\right.$ or $\left.5-\mathrm{H}_{\text {Py }}\right), 7.85\left(\mathrm{dd},{ }^{3} \mathrm{~J}=7.5,{ }^{4} \mathrm{~J}=\right.$ $\left.1.5,1 \mathrm{H}, 6-\mathrm{H}_{\mathrm{Py}}\right), 7.82\left(\mathrm{~d},{ }^{3} \mathrm{~J}=1.8,1 \mathrm{H}, \mathrm{NCH}\right), 7.12$ (ddd, ${ }^{3} \mathrm{~J}=7.2,{ }^{3} \mathrm{~J}=5.7$ ${ }^{4} J=1.5,1 \mathrm{H}, 4-$ or $\left.5-\mathrm{H}_{\text {Py }}\right), 7.06\left(\mathrm{~s}, 2 \mathrm{H}, m-\mathrm{H}_{\mathrm{Mes}}\right), 6.80\left(\mathrm{~d},{ }^{3} \mathrm{~J}=1.8,1 \mathrm{H}, \mathrm{NCH}\right)$, $5.68\left(\mathrm{~s}, 2 \mathrm{H}, \mathrm{CH}_{2}\right), 4.99\left(\mathrm{~s}, 5 \mathrm{H}, \mathrm{C}_{5} \mathrm{H}_{5}\right), 2.39\left(\mathrm{~s}, 3 \mathrm{H}, p-\mathrm{CH}_{3}\right), 2.05(\mathrm{~s}, 6 \mathrm{H}, 0$ $\left.\mathrm{CH}_{3}\right) \cdot{ }^{13} \mathrm{C}\left\{{ }^{1} \mathrm{H}\right\} \mathrm{NMR}\left(\mathrm{CDCl}_{3}, 75 \mathrm{MHz}\right): \delta 162.5(\mathrm{NCN}), 158.8(3-\mathrm{Cpy}), 156.2$ (1-Сpy), 140.2 (ipso-129.6 ( $m$-С Mes $), 126.9\left(6-\mathrm{C}_{\text {py }}\right), 125.0\left(4-\mathrm{C}_{\mathrm{py}}\right), 124.6(\mathrm{NCH}), 123.4(\mathrm{NCH})$, $92.6\left(\mathrm{C}_{5} \mathrm{H}_{5}\right), 54.4\left(\mathrm{CH}_{2}\right), 21.3\left(p-\mathrm{CH}_{3}\right), 18.1\left(o-\mathrm{CH}_{3}\right)$.

\section{General procedure for the hydrosilylation of aldehydes 3 into} alcohols 4

An oven dried Schlenk tube containing a stirring bar was loaded with the nickel pre-catalyst 2a $(9.6 \mathrm{mg}, 0.02 \mathrm{mmol})$ and dry THF $(4 \mathrm{~mL})$. To the resulting green solution was added the aldehyde $(1.00 \mathrm{mmol})$ and $\mathrm{PhSiH}_{3}$ $(148 \mu \mathrm{L}, 1.20 \mathrm{mmol})$, in this order, and the reaction mixture was stirred in a preheated oil bath at $40{ }^{\circ} \mathrm{C}$ for $4 \mathrm{~h}$. The reaction mixture was then quenched by the addition of methanol $(2 \mathrm{~mL})$ and $2 \mathrm{M} \mathrm{NaOH}(2 \mathrm{~mL})$ and stirred for $2 \mathrm{~h}$. After the addition of water $(5 \mathrm{~mL})$, the product was extracted with diethylether $(3 \times 10 \mathrm{~mL})$. The combined organic layers were dried over anhydrous $\mathrm{MgSO}_{4}$, filtered and concentrated under vacuum. The conversion was determined by ${ }^{1} \mathrm{H}$ NMR spectroscopy, and the product purified by flash chromatography on silica gel using petroleum ether/diethyl ether (80:20 and 50:50) mixtures. All conversions and yields are the average value of at least two runs.

\section{General procedure for the hydrosilylation of ketones 5 into alcohols} 6.

An oven dried Schlenk tube containing a stirring bar was loaded with the nickel pre-catalyst $2 \mathrm{a}(4.8 \mathrm{mg}, 0.01 \mathrm{mmol}), \mathrm{KO} t$-Bu $(1.1 \mathrm{mg}, 0.01 \mathrm{mmol})$ and dry toluene $(2 \mathrm{~mL})$. To the resulting deep orange solution was added the ketone $(0.5 \mathrm{mmol})$ and $\mathrm{PhSiH}_{3}(74 \mu \mathrm{L}, 0.6 \mathrm{mmol})$, in this order, and the reaction mixture was stirred in a preheated oil bath at $100^{\circ} \mathrm{C}$ for $24 \mathrm{~h}$. The reaction mixture was then quenched by the addition of methanol $(2 \mathrm{~mL})$ and $2 \mathrm{M} \mathrm{NaOH}(2 \mathrm{~mL})$ and stirred for $2 \mathrm{~h}$. After the addition of water $(5 \mathrm{~mL})$, the product was extracted with diethylether $(3 \times 10 \mathrm{~mL})$. The combined organic layers were dried over anhydrous $\mathrm{MgSO}_{4}$, filtered and concentrated under vacuum. The conversion was determined by ${ }^{1} \mathrm{H}$ NMR spectroscopy and GC analysis, and the product purified by flash chromatography on silica gel using petroleum ether / ethyl acetate (80:20 and 50:50) mixtures. All conversions and yields are the average value of at least two runs.

\section{Acknowledgements}

The CNRS, the University of Strasbourg, and the Agence Nationale de la Recherche (ANR 2010 JCJC 716 1) are acknowledged for supporting and funding partially this work (postdoc of $S$. Shahane). The Institut Universitaire de France is acknowledged for its support (V.R.), and the Région Grand Est for the doctoral fellowship of F. Ulm. This work has also benefitted from support provided by the University of Strasbourg Institute for Advanced Study (USIAS) for a Fellowship, within the French national program "Investment for the future" (IdEx-Unistra) (C.M. and C.P.-H.) Mrs. Corinne Bailly and Dr. Lydia Karmazin are acknowledged for the X-ray structural determinations. Mrs. Alexandra Sutter (ICPEES) is gratefully thanked for her assistance with DLS measurements and discussion. Dr. Emeric 
Wasielewski (LIMA) is thanked for his assistance with NMR experiments.

\section{Keywords: Carbonyls $\cdot$ Hydrosilylation $\cdot \mathrm{N}$-heterocyclic carbenes $\cdot$ Nanoparticles $\cdot$ Nickel}

[1] a) P. G. Andersson, I. J. Munslow (Eds.), Modern Reduction Methods Wiley,New York, 2008; b) P. A. Dub, T. Ikariya, ACS Catal. 2012, 2 1718-1741; c) J. March, Advanced Organic Chemistry: Reactions, Mechanisms and Structures, Seventh Edition, Wiley-VCH, New York 2013.

[2] a) B. Marciniec, H. Maciejewski, C. Pietraszuk, P. Pawluć in Hydrosilylation: A Comprehensive Review on Recent Advances (Ed. B Marciniec), Springer, Heidelberg, 2009; b) D. Addis, S. Das, K. Junge, M. Beller, Angew. Chem. Int. Ed. 2011, 50, 6004-6011; Angew. Chem. 2011, 123, 6128-6135; c) S. Werkmeister, K. Junge, M. Beller, Org Process Res. Dev. 2014, 18, 289-302; d) K. Revunova, G. I. Nikonov, Dalton Trans. 2015, 44, 840-866; e) J. Pesti, G. L. Larson, Org. Process Res. Dev. 2016, 20, 1164-1181; f) M. Oestreich, Angew. Chem. Int. Ed. 2016, 55, 494-499; Angew. Chem. 2016, 128, 504; g) M. C. Lipke, A. L. Liberman-Martin, T. D. Tilley, Angew. Chem. Int. Ed. 2017, 56, 2260 2294; Angew. Chem. 2017, 129, 2298-2332.

[3] a) A. Correa, O.G. Mancheno, C. Bolm, Chem. Soc. Rev. 2008, 37, 1108-1117; b) C. Wang, X.F. Wu, J.L. Xiao, Chem. Asian J. 2008, 3, 1750-1770; c) P.J. Chirik, in: Catalysis without Precious Metals, WileyVCH, 2010, pp. 83-110; d) M.S. Holzwarth, B. Plietker, ChemCatChem 2013, 5, 1650-1679; e) R. M. Bullock, Science 2013, 342, 1054-1055; f) S.W.M. Crossley, C. Obradors, R.M. Martinez, R.A. Shenvi, Chem. Rev. 2016, 116, 8912-9000; g) J. R. Ludwig, C. S. Schindler, Chem 2017, 2, 313-316.

[4] Hydrosilylation of aldehydes and ketones using first-row transition metals ( $\mathrm{Mn}, \mathrm{Fe}, \mathrm{Co}, \mathrm{Ni}, \mathrm{Cu}$ ), see: a) F. Jiang, D. Bezier, J.-B. Sortais, C. Darcel, Adv. Synth. Catal. 2011, 353, 239-244; b) L. C. Misal Castro, D. Bezier, J.-B. Sortais, C. Darcel, Adv. Synth. Catal. 2011, 353, 1279-1284; c) E. Buitrago, F. Tinnis, H. Adolfsson, Adv. Synth. Catal. 2012, 354, 217-222 d) D. Bezier, F. Jiang, T. Roisnel, J.-B. Sortais, C. Darcel, Eur. J. Inorg. Chem. 2012, 1333-1337; e) L. P. Bheeter, M. Henrion, L. Brelot, C. Darcel, M. J. Chetcuti, J.-B. Sortais, V. Ritleng, Adv. Synth. Catal. 2012 354, 2619-2624; f) L. Postigo, B. Royo, Adv. Synth. Catal. 2012, 354 2613-2618; g) J. Zheng, C. Darcel, J.-B. Sortais, Catal. Sci. Technol. 2013, 3, 81-84; h) A. J. Ruddy, C. M. Kelly, S. M. Crawford, C. A Wheaton, O. L. Sydora, B. L. Small, M. Stradiotto, L. Turculet, Organometallics 2013, 32, 5581-5588; i) Q. Niu, H. Sun, X. Li, H. F. Klein, U. Florke, Organometallics 2013, 32, 5235-5238; j) V. K. Chidara, G. Du, Organometallics 2013, 32, 5034-5037; k) V. Cesar, L. C. Misa Castro, T. Dombray, J.-B. Sortais, C. Darcel, S. Labat, K. Miqueu, J. M. Sotiropoulos, R. Brousses, N. Lugan, G. Lavigne, Organometallics 2013, 32, 4643-4655; I) S. J. Kraft, R. H. Sanchez, A. S. Hock, ACS Catal. 2013, 3, 826-830; m) J. Zheng, S. Elangovan, D. A. Valyaev, R. Brousses, V. César, J.-B. Sortais, C. Darcel, N. Lugan, G. Lavigne, Adv. Synth. Catal. 2014, 356, 1093-1097; n) H. Zhao, H. Sun, X. Li, Organometallics 2014, 33, 3535-3539; o) Z. Zuo, H. Sun, L. Wang, X Li, Dalton Trans. 2014, 43, 11716-11722; p) D. Kumar, A. P. Prakasham, L. P. Bheeter, J.-B. Sortais, M. Gangwar, T. Roisnel, A. C. Kalita, C. Darcel, P. Ghosh, J. Organomet. Chem. 2014, 762, 81-87; q) H. Zhou, H. Sun, S. Zhang, X. Li, Organometallics 2015, 34, 1479-1486; r) F. S. Wekesa, R. Arias-Ugarte, L. Kong, Z. Sumner, G. P. McGovern, M. Findlater, Organometallics 2015, 34, 5051-5056; s) M. A. Nesbit, D. L. M. Suess, J. C. Peters, Organometallics 2015, 34, 4741-4752; t) C. Ghosh, T. K. Mukhopadhyay, M. Flores, T. L. Groy, R. J. Trovitch, Inorg Chem. 2015, 54, 10398-10406; u) B. Xue, H. Sun, X. Li, RSC Adv. 2015 5, 52000-52006; v) S. Huang, H. Zhao, X. Li, L. Wang, H. Sun, RSC Adv. 2015, 5, 15660-15667; w) Y. Wei, S.-X. Liu, H. Mueller-Bunz, M. Albrecht, ACS Catal. 2016, 6, 8192-8200; x) T. C. Jung, G. Argouarch, P. van de Weghe, Catal. Commun. 2016, 78, 52-54; y) M. Rocquin, V. Ritleng, S. Barroso, A. M. Martins, M. J. Chetcuti, J. Organomet. Chem. 2016, 808, 57-62; z) X. Yu, F. Zhu, D. Bu, H. Lei, RSC Adv. 2017, 7, 15321-15329; aa) B. Xue, H. Sun, Q. Niu, X. Li, O. Fuhr, D. Fenske,
Catal. Commun. 2017, 94, 23-28; ab) S. Ren, S. Xie, T. Zheng, Y. Wang, S. Xu, B. Xue, X. Li, H. Sun, O. Fuhr, D. Fenske, Dalton Trans. 2018, 47, 4352-4359; ac) Y. Li, J. A. Krause, H. Guan, Organometallics 2018, 37, 2147-2158; ad) X. Yang, C. Wang, Chem. Asian J. 2018, 13, 2307-2315, ae) X. Frogneux, F. Borondics, S. Lefrançois, F. D'Accriscio, C. Sanchez, S. Carenco, Catal. Sci. Technol. 2018, 8, 5073-5080; af) F. Ritter, D Mukherjee, T. P. Spaniol, A. Hoffmann, J. Okuda, Angew. Chem. Int. Ed. 2019, 58, 1818-1822; ag) D. G. A. Verhoeven, J. Kwakernaak, M. A. C van Wiggen, M. Lutz, M.-E. Moret, Eur. J. Inorg. Chem. 2019, 660-667; ah) Á. Raya-Barón, P. Oña-Burgos, I. Fernández, ACS Catal. 2019, 9 5400-5417; ai) O. Martínez-Ferraté, B. Chatterjee, C. Werlé, W. Leitner, Catal. Sci. Technol. 2019, 9, 6370-6378; aj) M. R. Elsby, R. T. Baker, Chem. Commun. 2019, 55, 13574-13577; ak) K. Kobayashi, D. Taguchi, T. Moriuchi, H. Nakazawa, ChemCatChem 2020, 12, 736-739; al) C. K. Blasius, H. Wadepohl, L. H. Gade, Eur. J. Inorg. Chem. 2020, 2335-2342.

[5] a) B. Royo, E. Peris, Eur. J. Inorg. Chem. 2012, 1309-1318; b) L. Benítez Junquera, F. E. Fernández, M. C. Puerta, P. Valerga, Eur. J. Inorg. Chem. 2017, 2547-2556.

[6] a) M. Henrion, A. M. Oertel, V. Ritleng, M. J. Chetcuti, Chem. Commun 2013, 49, 6424-6426; b) B. de P. Cardoso, J.-M. Bernard-Schaaf, S. Shahane, L. F. Veiros, M. J. Chetcuti, V. Ritleng, Dalton Trans. 2018, 47, 1535-1547.

[7] F. Ulm, A. I. Poblador-Bahamonde, S. Choppin, S. Bellemin-Laponnaz, M. J. Chetcuti, T. Achard, V. Ritleng, Dalton Trans. 2018, 47, 1713417145.

[8] a) A. A. D. Tulloch, A. A. Danopoulos, S. Winston, S. Kleinhenz, G. Eastham, J. Chem. Soc., Dalton Trans. 2000, 4499-4506; b) S. Warsink, C. M. S. van Aubel, J. J. Weigand, S.-T. Liu, C. J. Elsevier, Eur. J. Inorg. Chem. 2010, 5556-5562.

[9] a) C. D. Abernethy, A. H. Cowley, R. A. Jones, J. Organomet. Chem 2000, 596, 3-5; b) R. A. Kelly III; N. M. Scott, S. Díez-González, E. D. Stevens; S. P. Nolan, Organometallics 2005, 24, 3442-3447; c) V. Ritleng, C. Barth, E. Brenner, S. Milosevic, M. J. Chetcuti, Organometallics 2008, 27, 4223-4228; d) A. M. Oertel, J. Freudenreich, J. Gein, V. Ritleng, L. F. Veiros, M. J. Chetcuti, Organometallics 2011 30, 3400-3411; e) Ł. Banach, P.A. Guńka, J. Zachara, W. Buchowicz, Coord. Chem. Rev. 2019, 389, 19-58.

[10] CCDC 2081215 (2a) and CCDC 2081216 (2b) contain the supplementary crystallographic data which can be obtained free of charge via https://www.ccdc.cam.ac.uk/structures/.

[11] H. S. Gutowsky, C. H. Holm, J. Chem. Phys. 1956, 25, 1228-1234.

[12] V. Ritleng, A. M. Oertel, M. J. Chetcuti, Dalton Trans. 2010, 39, 81538160.

[13] a) G. J. Martin, M. L. Martin, J. P. Gouesnard, ${ }^{15} N-N M R$ spectroscopy in NMR basic principles and progress, Vol. 18 (Eds.: P. Diehl, E. Flick, R. Kosfeld), Springer-Verlag, Berlin, 1981, pp. 75-186; b) S. Berger, S. Braun, H.-O. Kalinowski, NMR spectroscopy of the non-metallic elements, Wiley, Chichester, 1997.

[14] a) S. H. Strauss, Chem. Rev. 1993, 93, 927-942; b) S. P. Smidt, N Zimmermann, M. Studer, A. Pfaltz, Chem. Eur. J. 2004, 10, 4685-4693; c) Y. Schramm, F. Barrios-Landeros, A. Pfaltz, Chem. Sci. 2013, 4, 2760-2766, and references therein.

[15] a) J. H. Docherty, J. Peng, A. P. Dominey, S. P. Thomas, Nat. Chem. 2017, 9, 595-600; b) J. Peng, S. P. Thomas, Synlett 2020, 31, 11401146.

[16] V. M. Chernyshev, O. V. Khazipov, M. A. Shevchenko, A. Y. Chernenko A. V. Astakhov, D. B. Eremin, D. V. Pasyukov, A. S. Kashin, V. P. Ananikov, Chem. Sci. 2018, 9, 5564-5577.

[17] For the hydrosilylation of sterically hindered ketones to alcohols, see: a) B. Tao, G. C. Fu, Angew. Chem. Int. Ed. 2002, 41, 3892-3894; Angew. Chem. 2002, 114, 4048-4050; b) D. A. Evans, F. E. Michael, J. S. Tedrow, K. R. Campos, J. Am. Chem. Soc. 2003, 125, 3534-3543; c) B. H. Lipshutz, C. C. Caires, P. Kuipers, W. Chrisman, Org. Lett. 2003, 5, 3085-3088; d) S. Diez-Gonzalez, H. Kaur, F. K. Zinn, E. D. Stevens, S. P. Nolan, J. Org. Chem. 2005, 70, 4784-4796; e) S. Diez-Gonzalez, N. M. Scott, S. P. Nolan, Organometallics 2006, 25, 2355-2358; f) G. Hamasaka, A. Ochida, K. Hara, M. Sawamura, Angew. Chem. Int. Ed. 2007, 46, 5381-5383; Angew. Chem. 2007, 119, 5477-5479; g) T. 
Fujihara, K. Semba, J. Terao, Y. Tsuji, Angew. Chem. Int. Ed. 2010, 49 , 1472-1476; Angew. Chem. 2010, 122, 1514-1518.

[18] F. Ulm, Y. Cornaton, J.-P. Djukic, M. J. Chetcuti, V. Ritleng, Chem. Eur. J. 2020, 26, 8916-8925.

[19] L. P. Bheeter, M. Henrion, M. J. Chetcuti, C. Darcel, V. Ritleng, J.-B. Sortais, Catal. Sci. Technol. 2013, 3, 3111-3116.

[20] S. Pelties, D. Herrmann, B. de Bruin, F. Hartlc, R. Wolf, Chem. Commun 2014, 50, 7014-7016

[21] R. H. Crabtree, Chem. Rev. 2012, 112, 1536-1554.

[22] V. Papaefthimiou, D. K. Niakolas, F. Paloukis, T. Dintzer, S. Zafeiratos, ChemPhysChem 2017, 18, 164-170.

[23] a) J.-F. Soule, H. Miyamura, S. Kobayashi, J. Am. Chem. Soc. 2013, 135 10602-10605; b) M. Díaz de los Bernardos, S. Pérez-Rodríguez, A. Gual, C. Claver, C. Godard, Chem. Commun. 2017, 53, 7894-7897.

[24] V. M. Chernyshev, E. A. Denisova, D. B. Eremin, V. P. Ananikov, Chem. Sci. 2020, 11, 6957-6977. 
